\title{
DO HEAVY METALS AFFECT ON DEHYDRATION RATE OF BRASSICA NAPUS, TRITICUM SPP., ZEA MAYS AND HORDEUM VULGARE? VAI SMAGIE METĀLI IETEKME BRASSICA NAPUS, TRITICUM SPP., ZEA MAYS UN HORDEUM VULGARE DEHIDRĀCIJAS PAKĀPI?
}

\author{
N. Suchkova ${ }^{1}$, T. Sawidis ${ }^{2}$, J. Ganoulis ${ }^{3}$ \\ 1- Department of Environmental Engineering and Management, National Academy of Municipal \\ Economy, Kharkiv, 61002, Revolutsii Str.12, UKRAINE \\ Tel.: +30 2310 995682, Fax: +30 2310 995681, Email: Suchkova_Natasha@ukr.net \\ 2- Department of Botany, Aristotle University of Thessaloniki, Gr-54006 Thessaloniki, \\ Macedonia, GREECE \\ Tel.: +30 2310 998294, Fax: +30 2310 998389, Email: sawidis@ bio.auth.gr \\ 3- Department of Civil Engineering, Aristotle University of Thessaloniki, Gr-54006 Thessaloniki, \\ Macedonia, GREECE \\ Tel.: +30 2310 995682, Fax: +30 2310 995681, Email: iganouli@ civil.auth.gr

\begin{abstract}
Dependence of dehydration rate of Brassica napus, Triticum spp., Zea mays and Hordeum vulgare from heavy metal concentrations in plants after its growth in contaminated media has been studied in the laboratory and results are summarized in this paper. We found water loss reduction in all plant species germinated in sewage sludge (somewhere soil) after 18 day in comparison with control samples, presented by garden compost. Moreover, water loss was reduced significantly in root part of the plants. At the same time water loss was increased in Brassica napus, Triticum spp. and Hordeum vulgare germinated in sewage sludge after 30 day in comparison with control samples that could have been caused by metals interactions with plants' metabolic processes within the cells.
\end{abstract}

Keywords: water loss (dehydration rate), heavy metals, sewage sludge, Brassica napus, Triticum spp., Zea mays, Hordeum vulgare, germination.

\section{Introduction}

Heavy metals are important environmental pollutants and many of them are toxic even at very low concentrations $(\mathrm{Cd}, \mathrm{Hg}, \mathrm{Pb}, \mathrm{Cr}, \mathrm{Zn}, \mathrm{Ni}, \mathrm{As})$. The remediation efforts represent a substantial financial burden for industry, government and taxpayers. Anthropogenic metal inputs include spoil from metal mining operations, fallout from refinery emissions, waste disposal, electroplating, combustion of fossil fuels, and agricultural application of pesticides and biosolids [5]. Traditional remediation efforts (e.g. excavation, burial and contaminant isolation) are not feasible for large-scale impacts and therefore alternative remediation strategies are necessary when vast areas of land have been contaminated. Hyperaccumulator plants concentrate trace metals in their harvestable biomass, thereby offering a sustainable treatment option for metalcontaminated sites.

To study capability of phytoremediation we chose two objects, where metal-contaminated sites are presented. They are Wastewater Treatment Plant Sindos, Thessaloniki, Greece, where contamination of site is caused by sewage sludge storage, and area neighboring with Agios Dimitrios coal power plant of Thessaloniki, Greece. In the phytoexperiment Brassica napus (Brassicaceae family), Triticum spp., Zea mays and Hordeum vulgare (Poaceae family) were used. Brassica napus is among the best accumulators of heavy metals, especially $\mathrm{Ni}$ and $\mathrm{Zn}$. Triticum spp., Zea mays and Hordeum vulgare was chosen as the most productive biomass accumulators [3]. During the research the main focus was made on controlling of the dependence between water loss of the plants and its heavy metal content. Do heavy metals affect on dehydration rate of chosen plants? Can we predict the metal concentrations in the plants only with 

Zea Mays and Hordeum Vulgare?

knowledge about its water loss, without metals measurements? Which are the limits of phytotoxicity of different plant species? These are the questions, which we were asked on and which we tried to clarify in present paper.

\section{Preparation of the experiment}

\section{Materials and Methods}

Three substrates were used in this study: soil, sewage sludge and garden compost. Soil samples from a depth of 5-10 cm from the soil surface were collected on cultivated area, 200-300 meters away from the Agios Dimitrios coal power plant of Thessaloniki, Greece (it is located in the Kozani-Ptolemaida-Amynteon lignite basin in West Macedonia among with three other lignite power plants producing about $70 \%$ of the total electric energy in Greece). Dewatered with filterpresses sewage sludge was taken at Wastewater Treatment Plant in Sindos (treatment of domestic wastewaters only). Garden compost was used for the control samples. In the experiment Brassica napus, Triticum spp., Zea mays and Hordeum vulgare were grown in pots with soil, sewage sludge and garden compost during 30 day-period. Ten seeds of each plant species were sown directly onto the substrate on the pots. Plants were watered as often as they needed. After 18-day and 30-day period of cultivation, the shoots and roots were collected, left to be dry in room temperature until constant weight (water loss measurements), after dried in an oven at $65{ }^{\circ} \mathrm{C}$ and further crushed and digested with set of acids with the aim to determine heavy metal concentrations.

\section{Analytical methods for sample pretreatment}

The wet digestion of organic matrix sampled (plants, sludge, soil, compost) by use of concentrated $\mathrm{HNO}_{3}$ and $\mathrm{HCLO}_{4}+\mathrm{HF}+\mathrm{HCl}$ as the most common procedure was used for sample pretreatment [4].

An accurately weighted portion of each plant, sludge or compost sample $(0.2 \mathrm{~g}$ dry weight $)$ was placed in teflon beaker. About $20 \mathrm{ml}$ of concentrated $\mathrm{HNO}_{3}$ was added to each beaker and the mixture covered with a cup was left at room temperature on 24 hours. Then it was heated to near dryness on a sand bath, subsequently dissolved in $20 \mathrm{ml} 1+1 \mathrm{HNO}_{3}$ and heated on a sand bath during 30min exactly. The residue was diluted to $200 \mathrm{ml}$ with d-distilled water (beakers were washed with d-distilled water twice).

Soil samples were pretreated using the same procedure, however in that case at the beginning $\mathrm{HClO}_{4}$ and concentrated $\mathrm{HF}$ were used and during the second heating on a sand bath (30 min) $1+1$ $\mathrm{HCl}$ was used.

These final solutions were analyzed for heavy metal concentrations.

Determination of metals by Atomic Absorption Spectrometry

The determination of $\mathrm{Cd}, \mathrm{Cu}, \mathrm{Ni}, \mathrm{Pb}, \mathrm{Zn}, \mathrm{Cr}$ was carried out by atomic absorption spectrometry, with flame and graphite furnace modes. A Perkin Elmer 503 Atomic Absorption Spectrometer was used coupled with a THGA-800 graphite furnace controller. The concentrations are given in milligrams per kilogram dry weight.

\section{Results and Discussion}

Plants distribute metals internally in many different ways. They may localize selected metals mostly in roots and stems, or they may accumulate and store other metals in nontoxic form for later distribution and use. A mechanism of tolerance or accumulation in some plants apparently involves binding potentially toxic metals at cell walls of roots and leaves, away from sensitive sites within the cells or storing them in a vacuolar compartment.

In present research studying water loss of the plants and checking metal concentrations with AAS we tried without microscope technique to determine, where plants perhaps may localize metals.

In nature, the rate of evaporation from wet plants as Brassica napus, Zea mays, etc. surface depends on a few factors: the temperature at the plants surface; the atmospheric humidity, both at 
Suchkova N., Sawidis T., Ganoulis J. Do heavy metals affect on dehydration rate of Brassica Napus, Triticum Spp., Zea Mays and Hordeum Vulgare?

the plants surface and in the air; and wind speed. In the present study observing the impact of heavy metals on the water status of plants we kept the above-mentioned factors constant.

18 day of germination. Water loss was significantly reduced in Zea mays germinated on as soil (in shoots) well as sludge (in shoots) (Fig.1). At the same time in Zea mays in root parts germinated on the same media water loss was increased significantly. We considered compost as conditionally clean substrate, i.e. free of heavy metals (significant concentrations), and from the graph it is shown that water loss in Zea germinated on compost is intensive.

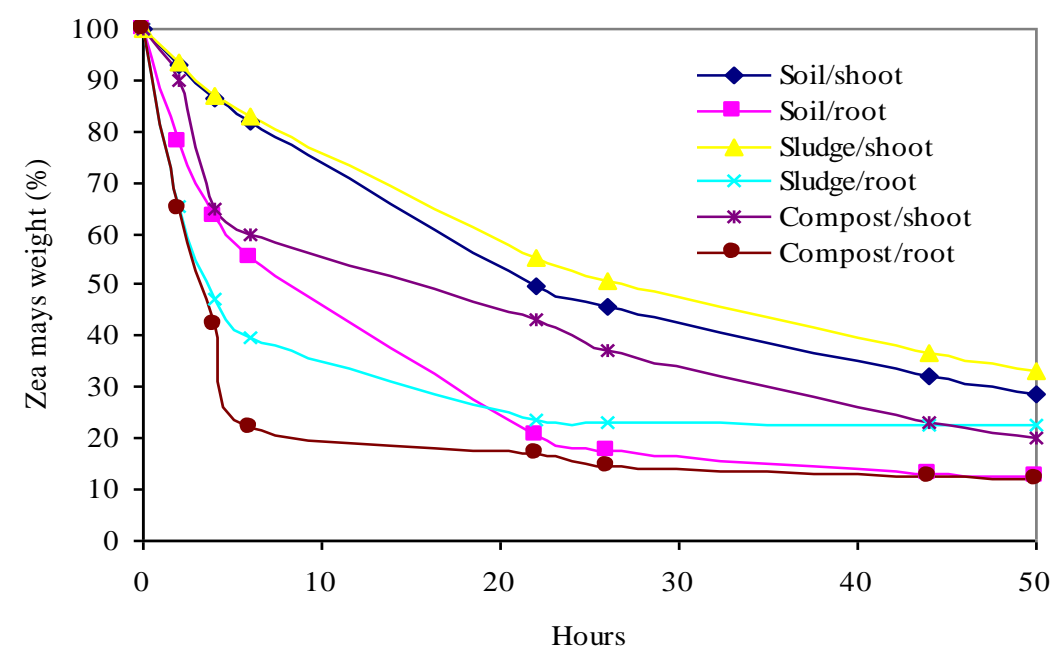

Fig.1. Water loss in Zea mays germinated in contaminated media after $18 \mathrm{~d}$

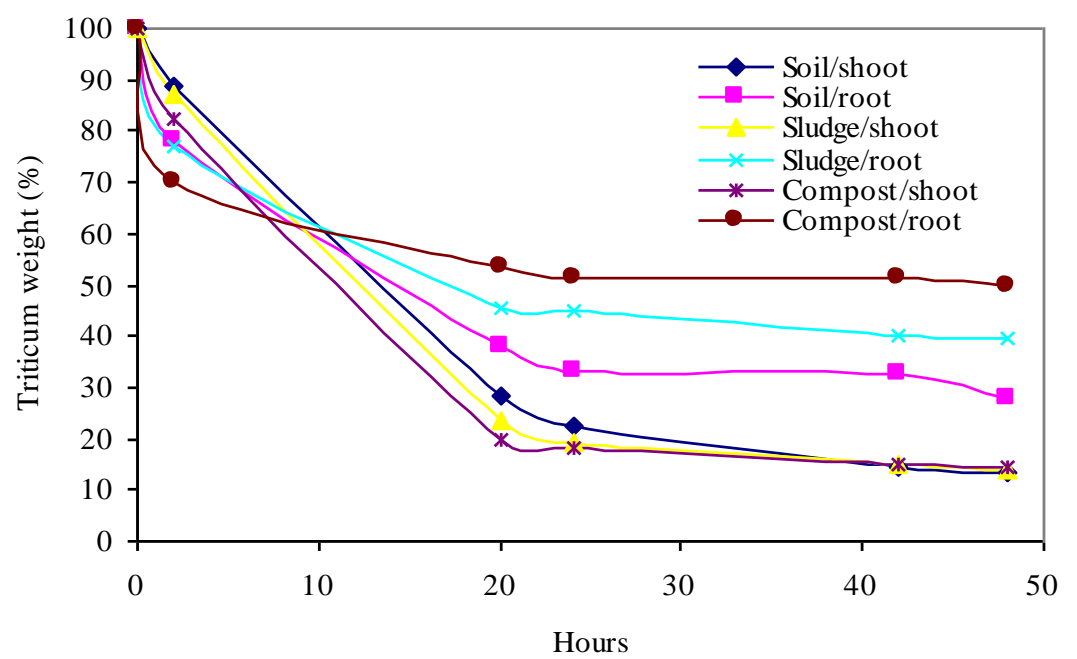

Fig.2. Water loss in Triticum spp. germinated in contaminated media after $18 \mathrm{~d}$

Water loss from the plants is not a simple physical process, but is guided by the energy budget, which is necessary for running different physiological processes and also for conversion of water into water vapor. 


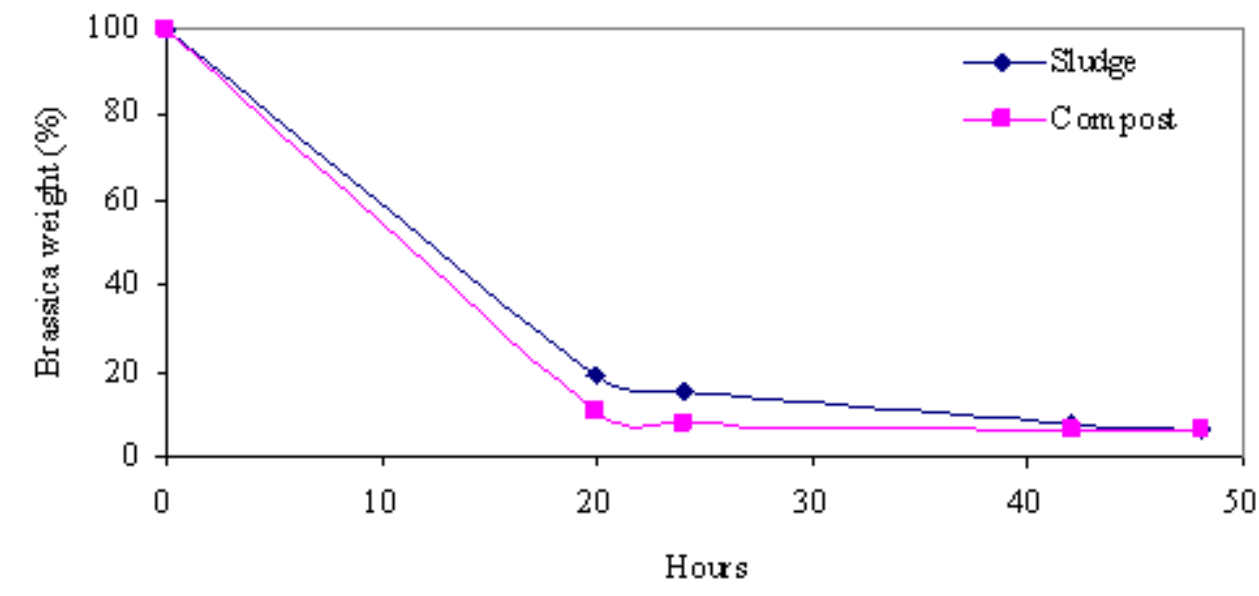

Fig.3. Water loss in Brassica napus germinated in sewage sludge after $18 \mathrm{~d}$

However, it was pointed out that a change in a single component of the energy exchange system changes the entire balance of the energy balance with water vapors. [2]. Therefore, the hypothesis tested in the present project was that heavy metal uptake affects water loss from selected plants.

The direct interaction of metals with cellular components can initiate a variety of metabolic responses. Some metals can pass through the plasma membrane of the plants cells (Zn), while others are obstructed by it $(\mathrm{Pb}, \mathrm{Cu})$ [2]. Thus, it is apparently that reduced water loss in Zea mays, germinated on sewage sludge and soil, was caused by the fact that heavy metals as $\mathrm{Pb}$ and $\mathrm{Cu}$ did not pass inside of the cells, were localized extracellularly and therefore helped in retention of water from the plant. At the same time we observed intensive water loss in Zea mays, germinated in control pots with the compost.

Similar situation we observed with Triticum spp. (18 day of germination) and Brassica napus (18 day of germination): diminished water loss must be due to high concentration of metals around the cells in comparison with control samples (compost).

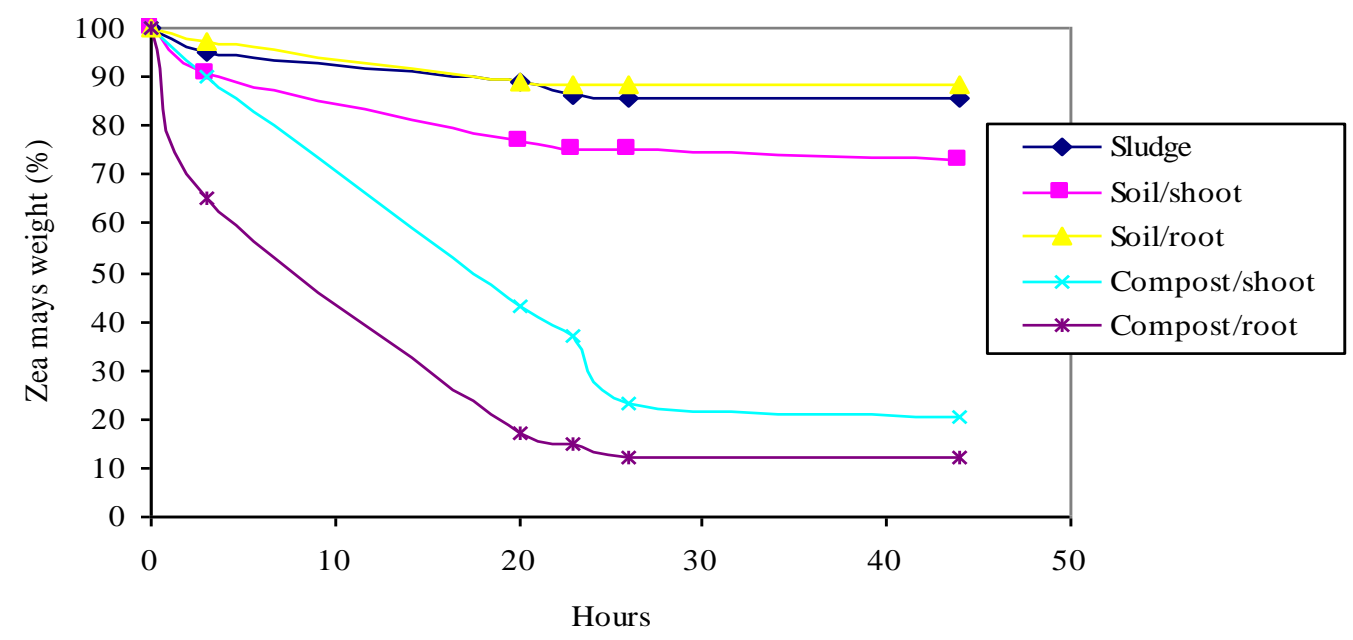

Fig.4. Water loss in Zea mays germinated in contaminated media after $30 \mathrm{~d}$ 


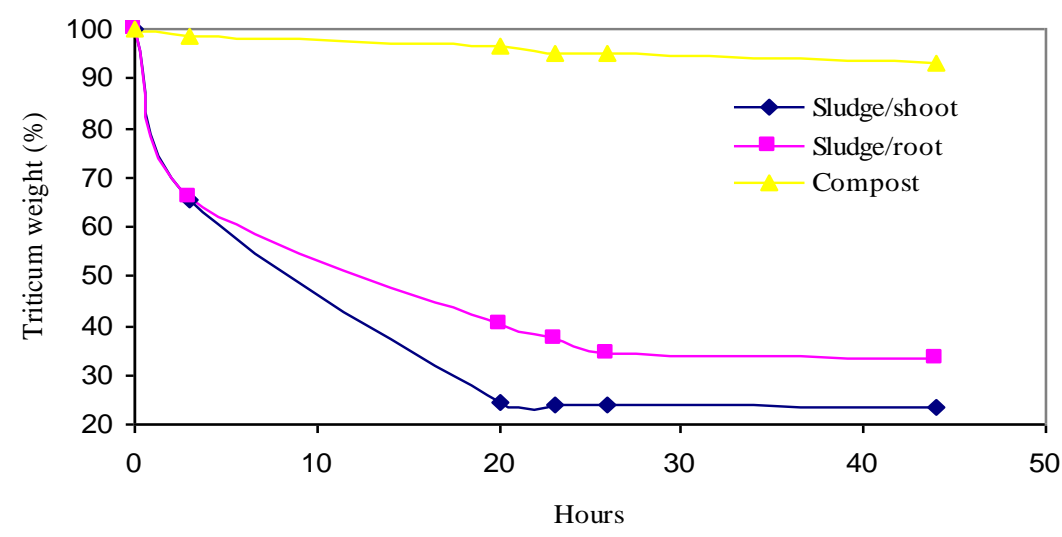

Fig.5. Water loss in Triticum spp. germinated in sludge after $30 \mathrm{~d}$

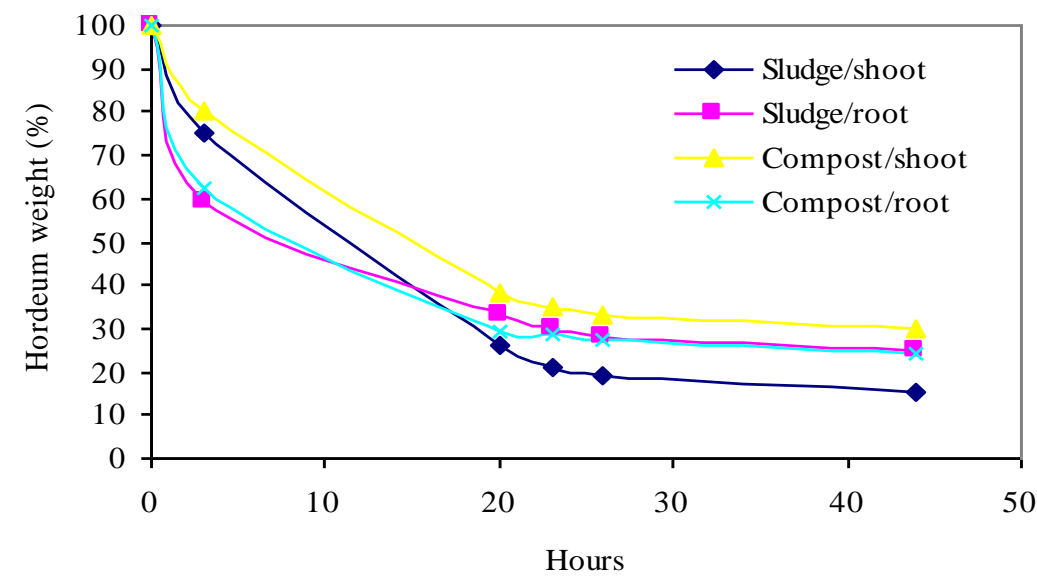

Fig.6. Water loss in Hordeum vulgare germinated in sewage sludge after $30 \mathrm{~d}$

Interaction of $\mathrm{Cu}$ with $\mathrm{SH}$ group leads to oxidative destruction of membrane lipids [2]. Thus, this infers that, due to the toxic effect of $\mathrm{Cu}$, normal metabolic activities like photophosphorylation were decreased and membrane lipids were destroyed and this must be the reason for faster water loss in Triticum spp., germinated on sewage sludge after 30 day, where we found higher $\mathrm{Cu}$ concentration in comparison with the control (Fig.7).

Water loss in Hordeum vulgare, germinated in sludge on $30^{\text {th }}$ day was not differed significantly from the control, because concentrations of heavy metals were not too high and were not differed in plants, germinated in sludge and compost (Table 1).

Metals content in Hordeum vulgare after $30 \mathrm{~d} ., \mathrm{mg} / \mathrm{kg}$

Table 1.

\begin{tabular}{|l|l|l|l|l|l|l|}
\hline Sample & Cd & Cu & Ni & Pb & Zn & Cr \\
\hline Hordeum_Sludge & 0 & 29 & 0 & 3 & 58 & 4 \\
\hline Hordeum_Compost & 0 & 29 & 42 & 2 & 42 & 25 \\
\hline
\end{tabular}






Fig.7. Concentration of $\mathrm{Cu}$ in plants tissue in comparison with a control sample

\section{Conclusion}

From the results, both water loss graphs and the analyses of heavy metal concentrations with AAS we may conclude that metal accumulation affects water potentials of the Brassica napus, Zea mays, Triticum spp. and Hordeum vulgare. It is inferred that heavy metals extracellularly localized help in retention of water in all selected plants, but once they enter the cell, they interfere with metabolic processes and accelerate water loss. In plants contained high $\mathrm{Pb}$ concentration (Zea mays, Triticum spp.) water loss was reduced in comparison with control plants, indicating that its plasma membrane acts as a barrier for $\mathrm{Pb}$ uptake. Measurement of water loss of the plants during phytoremediation could be useful for forecasting of real heavy metal concentration in the plants, in case of impossibility of metal measurements application (for instance, with ASS).

\section{Acknowledgments}

N. Suchkova thanks the Erasmus Mundus External Cooperation Window Lot 6 for awarding scholarship and Aristotle University of Thessaloniki, especially Department of Civil Engineering, Department of Botany and Department of Chemical Engineering, personally professor Mitrakas Manassis, for their support in current research.

\section{Bibliography}

1. Alcantara E., Ginhas A.M., Ojeda M.A. Metal accumulation by different plant species grown in contaminated media. W.J. Horst et.al. (Eds.), Plant nutrition - Food security and sustainability of agro-ecosystems. Kluwer Academic Publishers. Printed in the Netherlands, 2001. 460-461.p.

2. Chettri M.K., Sawidis T. Impact of heavy metals on water loss from lichen thalli. Ecotoxicology and environmental safety 37, 1997. 103-111.p.

3. Marmiroli N. Samotokin B., Marmiroli M. Advanced science and technology for biological decontamination of sites affected by chemical and radiological nuclear agents. NATO Science Series. Series IV. Earth and Environmental Sciences - Vol.75., 2006.

4. Miller R.J., and Miller J.N. Statistics for Analytical Chemistry. Ellis Horwood, Chichester, 1986.

5. Tappero R., Peltier E., Grafe M. Hyperaccumulator Alyssum murale relies on a different metal storage mechanism for cobalt than for nickel. New Phytologist 175, 2007. 641-654.p. 